\title{
Az alvás és az emésztés kapcsolata
}

| Szakács Zoltán dr.

MH EK, Neurológiai Osztály, Budapest

Correspondence: alvas@t-online.hu

A cirkadián ritmus és az alvás számos élettani funkciót befolyásol, beleértve az emésztőrendszert is. A legújabb kutatások kimutatták, hogy az alvás és a cirkadián tényezők egyértelműen befolyásolják az étvágyat, a tápanyagok felszívódását és az anyagcserét. Az alvás és a cirkadián ritmus zavarai ronthatják az emésztési rendellenességeket, beleértve a refluxot, a fekélyeket, a gyulladásos és irritábilis bélbetegségeket és gasztrointesztinális rákot. Ahogy gyarapodik tudásunk a cirkadián időzítés és a gasztrointesztinális élettan közötti kapcsolatról, úgy növekednek a lehetöségeink a gasztrointesztinális rendellenességek új diagnosztikai és terápiás megközelítésére.

KULCSSZAVAK: emésztés, emésztőrendszeri betegségek, gasztrointesztinális reflux, alvás, cirkadián ritmus

\section{The relationship between sleep and digestion}

Circadian rhythms and sleep influence a variety of physiological functions, including the digestive system. The digestive system also has intrinsic rhythms that interact dynamically with circadian rhythms. New advances in understanding the interaction of these rhythms and sleep provide the prospect of evaluating their role in normal physiology and the link of their disruption to pathological conditions. Recent work has demonstrated that sleep and circadian factors influence appetite, nutrient absorption, and metabolism. Disruption of sleep and circadian rhythms may increase vulnerability to digestive disorders, including reflux, ulcers, inflammatory bowel issues, irritable bowel disease, and gastrointestinal cancer. As our knowledge of the link between circadian timing and gastrointestinal physiology grows, so do our opportunities to provide promising diagnostic and therapeutic approaches for gastrointestinal disorders.

KEYWORDS: digestion, digestive diseases, gastrointestinal reflux, sleep, circadian rhythm

\section{Az alvás általános ismertetése és élettani hatása}

Az alvás- és az ébrenlétciklikus váltakozása az élőlények alapvető ritmusa. Az aktivitás és nyugalom, a lehető legmagasabb rendű alkalmazkodás. Alvásunk és ébrenlétünk alatt zajló biológiai és pszichológiai folyamatok szervesen kapcsolódnak egymáshoz, egységes folyamatot képezve, amelynek tartós, vagy ismételt megszakadása, zavara súlyos következményekkel járhat.

Ez magyarázza, hogy az alvás fiziológiás folyamatának rendellenességei sok esetben ébrenlétünk idején megnyilvánuló anyagcsere, vegetatív és központi idegrendszeri, valamint pszichés zavarokat okoznak. Az alvás sajátos viszonyai között viszont olyan kóros légzési-keringési, mozgás- és magatartásjelenségek alakulhatnak ki, amelyek az alvás és ébrenlét krónikus, súlyos következményekkel járó zavarát eredményezik. Számos krónikus betegségben szenvedő az alvás viszonyai között váratlanul kerülhet veszélyeztetett állapotba.

\section{Az alvás elektrofiziológiai és poliszomnográfiás jellemzői}

Az alvásfolyamat sokrétűségére, ciklusos szerkezetére utaló információkat az alvó külső megfigyelésével már a múlt század végén is szereztek a kutatók. Az alvás pontos, részletes és tudományos jellegű vizsgálatát azonban csak speciális módszerek több lépcsőben történő kialakulása tette lehetővé. 


\section{A non-REM- és a REM-alvás}

Az alvás két, egymástól és az ébrenléti állapottól eltérő fiziológiai állapotot foglal magába: a paradox, vagy REM-alvást, illetve a lassú hullámú, ortodox, vagy non-REM-alvást. (A REM-alvás nevét a mozgásvihar formájában jelentkező gyors szemmozgások angol megfelelőjének - Rapid Eye Movement - rövidítéséből kapta).

\section{A non-REM-alvás}

Az alvás változékony állapotok során alakul ki. Ez a változékony és összetett átmenet az éber állapot és az alvás között, fiziológiás helyzetben az alvásszükséglet szubjektív megélésével, az álmosságérzettel kezdődik és a szendergés állapotán keresztül vezet az alvásig.

\section{A REM-alvás}

Az alvó ébreszthetősége a non-REM-alváshoz viszonyítva rosszabb. Jellemzőit ún. tónusos, illetve fázisos jelenségekre osztjuk.

\section{Az alvás mintázata, az alvásszerkezet}

Az alvásfolyamatban az egyes fázisok jellegzetes, program szerinti sorrendbe szerveződnek, kialakítva az alvás ciklusos szerkezetét. Az alvás élő, változó, környezeti és belső ingerekre reagáló dinamikus folyamat, számos fázisok közötti oszcillációval. Az egyes alvásstádiumok leírásából is kiderül, hogy azok között nincs borotvaéles határ. Éppen ezért az alvásszerkezet ábrázolásának, amely nem más, mint a háttérben lévő alvásprogram mintázata sokféle típusa létezik. A gyakorlatban az alvás makrostruktúrájával foglalkozunk elsősorban.

A hipnogram úgy jön létre, hogy az alvást koordinátarendszerben ábrázoljuk, ahol a vízszintes tengelyen az időt, a függőleges tengelyen - egyezményes skálán - az alvásstádiumokat tüntetjük fel előfordulásuk sorrendjében és tartamuk szerint. A hipnogram lényegében a csak részleteiben megismert alvásprogramnak a mennyiségi-képi ábrázolása. Fiziológiás esetben elalvás után mélyülő, majd fokozatosan felszínessé váló sorrendben a non-REM-alvás stádiumain keresztül jutunk el az első REM-fázisig. Így válik teljessé egy alvásciklus. Tartama átlagosan 90 perc és egy éjszakai alvás során 4-6 alkalommal ismétlődik, jellemzően változó összetétellel: az alvás első harmadában egy cikluson belül a mély non-REM-alvás dominál, majd fokozatosan háttérbe szorul, a non-REM-alvás a későbbi ciklusokon mind felszínesebb lesz.

A REM-alvás ellentétes utat jár be: az alvás második felére e fázis mind tartamban, mind denzitásban növekedést mutat. A naponta alvással töltött idő, illetve az alvás szerkezete az életkorral párhuzamosan jellemző módon változik. Egészséges fiatal felnőtt naponta 6-8 órát tölt alvással, amelynek a REM-alvás 25, a felszínes non-REM-alvás 55, a mély non-REM-alvás 20\%-át teszi ki. Az újszülött naponta 16-18 órát alszik, a napi alvásigény 1 éves korra 12 órára, 10 éves korra 10 órára, serdülő korra 8 órára rövidül. 40 év felett ez az alvásigény ismét csökkenni kezd, 60 éves kor körül már naponta 5-6 óra alvás is elegendő.
Újszülöttekben a non-REM-alvást az ún. nyugodt alvás a REM-alvást az aktív alvás helyettesítik, amelyekből 1 éves kor körül fejlődik ki a REM- és non-REM-alvás. Csecsemő-, gyermek- és felnőttkorban a REM- és mély non-REM-alvás aránya meghaladja a fiatal felnőttkorban észlelt arányokat. A REM-alvás aránya újszülött-kortól az első életév végéig 50\%-ról 25-30\%-ra csökken. A non-REM-alvás részaránya pubertáskorig némi emelkedést mutat, benne gazdagodik az alvásiorsó-tevékenység. Magasabb életkorokban ugyanakkor e két alvásforma mennyisége - föleg a mély non-REM-alvás - fokozatosan csökken.

Az újszülött csaknem az egész napot átalussza. Kisgyermekkorban alvásunk jellemző módon kétpólusúvá válik, a napi alvásmennyiség egy hosszabb éjszakai és egy rövidebb kora-délutáni szakaszra oszlik. Felnőttkorban a délutáni alvás - az emberek túlnyomó többségében környezeti, szociális hatások eredményeként - visszaszorul, időskorban azonban, nem egyszer a felszínes és rövid éjszakai alvás kiegészítőjeként, ismét megjelenik. Az alvás szerkezete igénybevétel és környezeti behatások szerint is változhat, a fizikai és szellemi megterhelésnek megfelelően elsősorban a mély lassú hullámú alvás és a REM-alvás mennyisége növekszik. Ez a képesség az életkor növekedésével fokozatosan csökken.

\section{Az alvás-ébrenlét szabályozás homeosztatikus, cirkadián és ultradián komponensei}

Az alvás és az ébrenlét váltakozása, az alvás szerkezeti jellemzői, a hozzájuk csatlakozó anyagcsere- és hőmérsékletmutatók egyaránt arra utalnak, hogy az alvás kialakulásában több, mind az alkalmazkodást, mind a homeosztázist segítő egymással szoros kapcsolatban működő szabályozó mechanizmus vesz részt. A változások leírása, humán és állatkísérletek három alapvető tényezőt, a homeosztatikus, a cirkadián, illetve az ultradián komponens létét igazolták. A homeosztatikus komponens a mély non-REM-alváshoz kötődik, lényegében szabályozza az ébrenléti aktivitás tartama (minél tovább vagyunk ébren, annál álmosabbak leszünk) és az azt követő restoratív mély (lassú delta) non-REM-alvás mennyisége közötti fiziológiás egyensúlyt hivatott fenntartani. Abban nyilvánul meg, hogy az ébrenléti aktivitás tartamának és intenzitásának függvényében - egy exponenciális görbe mentén - megnövelt lassú hullámú alvásmennyiséget biztosít a követő alvás során. A mély lassú hullámú alvás pótlása - a REM-alvás pótlásával szemben - napszaktól függetlenül, ellenállhatatlanul következik be. Ma már bizonyított, hogy a lassú hullámú alvás visszacsapásos pótlása leginkább a homloklebenyt, a domináns agyféltekét és az aktuálisan túlterhelt agyi régiókat érinti.

A cirkadián és szemicirkadián komponens eredménye, hogy alváskészségünk nem egyformán oszlik el a nap során, hanem két kiugró pontot mutat 24 és 04 h, illetve 14 és 17 h között. Ezt a két időszakot elsődleges, illetve másodlagos alváskapunak is nevezik. Alváslaboratóriumi kísérletes helyzetben az is kiderült, hogy a 8-10 és a 17-19 óra közötti időszakok - a cirkadián alváskésztetés csökkenése 
következtében - viszont az ébren maradásnak kedveznek Az éjszakai csúcs a maghőmérséklet mélypontjával, a napközbeni csúcs a maghőmérséklet kora-délutáni átmeneti csökkenésével jelentkezik egy időben. Az alvás 24 órás mennyiségének egy tömbben való jelentkezése a cirkadián szabályozás eredménye. Hatása abban is észlelhető, hogy az elkezdődött alvás tartamának is határt szab. Minél közelebb kezdődik az alvás az éjszakai maghőmérséklet mélypontjához, annál rövidebb ideig tart.

A délutáni csúcs a szemicirkadián komponens megnyilvánulása. A tartósan virrasztó, majd alvó személy alvásának homeosztatikus potenciálja (lassú delta-hullám tartalma) ekkor a legnagyobb. Az itt megjelenő alváskésztetést sokáig az étkezéskor felszabaduló peptidek és az inzulinmobilizáció hatásának tulajdonították. Ma már tudjuk, hogy ez központi szabályozás része. Az is kiderült, hogy a 24 óra során elfoglalt pozíciója az éjszakainál stabilabb. $E$ két időpontnak nagy gyakorlati jelentősége van. Minden alvásmegvonásból, illetve kóros okból ki nem elégített (a nap 24 órájára vonatkozó) alvásigény, ezekben az időszakokban akarattól független elalvás, enyhébb esetben különböző mértékben befolyásolható álmosság, vagy figyelemzavar formájában spontán törhet elő. Következményük jelentős teljesítménycsökkenés, illetve balesetveszély lehet.

Az alvás és ébrenlét egyénre jellemző cirkadián ritmusa a gyermek- és iskoláskoron keresztül a fiatal felnőttkorig épül és rögzül a környezet időjelző, időhatároló, életritmust befolyásoló tényezőinek hatására. E két komponens természetes a mediterrán emberek életvitelében, de nálunk is gyakran követhetik olyan foglalkozást űzők, akiket nem köt a meghatározott munkarend. A délutáni lehetőség kihasználása életkorfüggő is lehet. Az óvodáskorú gyermek azért alszik délután is, mert az éjszakai alvásmennyiség nem elégséges számára. Az idős ember, kevesebb napközbeni elfoglaltsági kényszer híján éjszakai, természetesen felszínes és rövid alvását pótolja. E komponensek szempontjából természetesen a "fiziológiás" helyzet a napközben aktív, éjszaka pihenő életvitel. Az egyén cirkadián ritmusa az életkorral párhuzamosan csökkenő mértékben tartós környezeti hatásra módosulni képes. Tartós éjszakás műszakban dolgozó fiatal felnőttek teljesítménye akkor „áll be”, amikor maghőmérsékletük profilja is megfordul.

Az ultradián komponens, amely éjszaka 90, nappal 120 perces ciklusokat képez, legszembetűnőbb módon az alvás szerkezetében, a non-REM-REM ciklusos váltakozásában nyilvánul meg. Az ultradián ritmus ébrenlétben a gyermek- és felnőttkor során fokozatosan háttérbe szorul és csak az éjszakai alvás marad fenn. Az alvás első harmadában a homeosztatikus non-REM igény - jelentős lassú alvás túlsúlyt okozva - „szétfeszíti” az ultradián komponens kereteit, ami aztán fokozatosan az alvás utolsó harmadában kerül következetesen előtérbe. E jelenségnek praktikus oka lehet: a REM-funkciók a non-REM-folyamatok eredményeire épülnek. Más szóval a REM alatti folyamatok eredményességének feltétele a non-NREM-alvás alatti restoratív, energiamegőrző, szintetizáló folyamatok maradéktalan befejezése.

\section{Az alvás-ébrenlét ritmus cirkadián szabályozása}

A biológiai folyamatok cirkadián (24 óra körüli) ritmusa a Földön kialakult élővilág általános jellemzője. Emberben a legszembetűnőbb cirkadián ritmusnak a naponta viszszatérő, bifázisos ébrenlét-alvás ciklusok számítanak. Az alvás-ébrenlét ciklicitás a belső óránk (az elülső hypothalamusban található nucleus suprachiasmatis) működésén alapul, ami számos egyéb élettani paraméter (testhőmérséklet, kortizol- és melatoninvérszint) cirkadián ritmusát is vezérli. A belső óránk hatását az endokrin hormonok és a vegetatív idegrendszer ritmusai közvetítik a periféria felé. A szervezet fiziológiás működésének alapfeltétele, hogy ezen ritmusok szinkronizáltan múködjenek, így a 24 órás nap egyes szakaiban a legjobb alkalmazkodást lehetővé tevő kombinációkat (ún. „state”-eket, állapotokat) képezzenek.

A cirkadián ritmusok endogének, a környezet időhatározó tényezőinek tartós kiiktatása esetében is fennmaradnak. Emberben az endogén alvás-aktivitás ritmus 24,3 óra körül van, ami azt jelenti, hogy a környezet időhatározó („Zeitgeber") tényezői, elsősorban a fény, étkezés, valamint a fizikai-szellemi aktivitás révén naponta igazodik hozzá a 24 órás ritmushoz.

Az alvás-ébrenlét cirkadián szabályozásában a melatoninrendszer is fontos szerepet kap. A melatoninvérszint emelkedése (kb. 2 órával a megszokott alvás kezdete előtt kezdődik, csúcspontját 0-2 óra között éri el).

A melatonin tirozinból képződik, a tirozin-hidroxiláz enzim aktiválódása révén. Ezt a folyamatot a sötétség és nyugalom serkenti; fényhatás, ébresztő inger, a szimpatikus aktivitás növekedése, az adrenalin és a hisztamin gátolják. A melatonin javítja az alvás stabilitását és támogatja a reprodukciós folyamatokat.

\section{Az ultradián szabályozás ma ismert tényezői}

Az ultradián ritmus az alvásszabályozásnak az egyén életében legkorábban megjelenő (a magzati élet utolsó harmad, újszülöttkor) formája, ami kezdetben a nap 24 órája során folyamatosan nyilvánul meg, később pedig napközben az ébrenlét nyomja el, bár a vegetatív szabályozásban, féltekei dominanciában ezen idő alatt is észlelhető.

\section{Az alvás általános ismertetése Élettani alapok}

A cirkadián ritmus készíti fel testünket olyan várható eseményekre, mint például táplálkozás, vagy a fizikai aktivitás. Mint mesteróra, a hypothalamusban elhelyezkedő szuprachiasmatikus mag felelős testünkben a cirkadián ritmus koordinálásáért és szinkronizálásáért. A szuprachiasmatikus mag, „, belső óránk” többszörös visszajelentő hurkot is tartalmazó feedback-rendszert alkalmaz, amely genetikai transzkripció, valamint egy sejtmag és sejtfehérje-rendszer 24 órán keresztül történő oszcillációján alapul (1). 
1. táblázat: A cirkadián ritmus és az alvásstádiumok hatása a digesztív funkciókra

\begin{tabular}{lcc|}
\hline Digesztív funkció & \multicolumn{1}{c}{ Cirkadián hatás } & Alvás stádiumhatás \\
\hline Nyálprodukció & $\mathrm{A}$ pH-változás lehetséges & Igen \\
\hline Nyelés/nyelöcső-motilitás & Nem & Igen \\
\hline Gyomorsav-szekréció & Igen & Nem tisztázott \\
\hline Gyomormotilitás & Nem tisztázott & Igen \\
\hline Bélfelszívódás & Igen & Nem tisztázott \\
\hline Bélmotilitás & Lehetséges & Igen \\
\hline Colonmotilitás & Lehetséges & Igen
\end{tabular}

Ez a ritmus azonban nem pontosan 24 óra, ezért az óránkat a környezetünkből származó információk segítségével („Zeitgeber" tényezők) mindig be kell állítani. A legerősebb időzítő információ az erős fény, de az étkezés is jelentősen befolyásolja a biológiai óránk fázisát. A szuprachiasmatikus mag a melatonin segítségével szinkronizálja a perifériás cirkadián ritmusú óráinkat. Emellett endokrin és autonóm idegrendszeri hatásokon keresztül is befolyásolja szervezetünk folyamatait.

A cirkadián ritmus, közelebbről az alvó állapot is befolyásolja a gasztrointesztinális traktus élettanát. Az alvás aktív folyamat és élesen különbözik az ébenléttől. Az alvásunk gyors szemmozgással kísért (REM) alvásra és a non-REM-(NREM) alvásra bomlik, ciklusosan. Egymástól különálló, jól elhatárolódó komplex neuronhálózatok - a hypothalamus, a diencephalon, és az agytörzs magjai - egymással kapcsolódva irányítják a központi idegrendszert (2). Ennek eredményeként az agy neurohumorális rendszerének működése az alvás állapotától függően eltérő lehet. Az NREM-alvás során jelentős paraszimpatikus túlsúly alakul ki, míg a REM-alvás idején, mind a szimpatikus, mind paraszimpatikus aktivitás fokozódik.

Egyes szabályozófunkciók (például hormonális szekréciók) alvásstádium-függők, míg mások cirkadián mintázatot mutatnak. Ez a megkülönböztetés a cirkadián ritmus és az alvásistádium-függés között akadémikusnak tűnhet, ám ennek alapvető jelentősége lehet a fiziológiás ha- tások értelmezésekor, vagy a terápia meghatározásánál. Az alvásfüggő funkciókat javíthatja az alvás folyamatosságának és mennyiségének kiigazítása, míg a cirkadián ritmussal kapcsolatos zavarok az alvás megfelelő időzítésével javíthatók (1. táblázat).

\section{Az étkezés és a cirkadián ritmus}

Az étkezésnek megkülönböztetett kulturális és endogén ütemezése van. Úgy tűnik, hogy az étkezés önmagában is egy specifikus cirkadián ritmusoszcillátor. Ez a beépülő oszcillátor szerepet játszik a napi előrevetített ételbevitel előrejelzésén keresztül számos hormon, beleértve a ghrelin, leptin, kortikoszteron, inzulin, glükagon és glükagon-like peptid-1 hormonális oszcillációjában. Ezek az étkezéshez kapcsolt oszcillátorok még ismereteink szerint nem pontosan lokalizáltak, de jelentős részük a gyomorban található (3).

A cirkadián óra nagy részét savtermelő mirigysejtek alkotják, amelyek ritmikusan szabadítanak fel ghrelint. A ghrelin közvetlen hatást gyakorol a szuprachiasmatikus magra (4). Emellett a ghrelin és a leptin direkt feedback-et gyakorol a hypothalamusra, és járulékos szerepük van az étkezési ciklus kialakításában az orexin és a melanokortin szabályozásán keresztül (3).

A cirkadián ritmus diszrupciója a fázis eltolódásával, illetve a ritmus teljes szétesésével jellemezhető. A fázisváltozással

\section{1. ábra: Alvás alatti reflux (háton fekvő testpozícióban)}

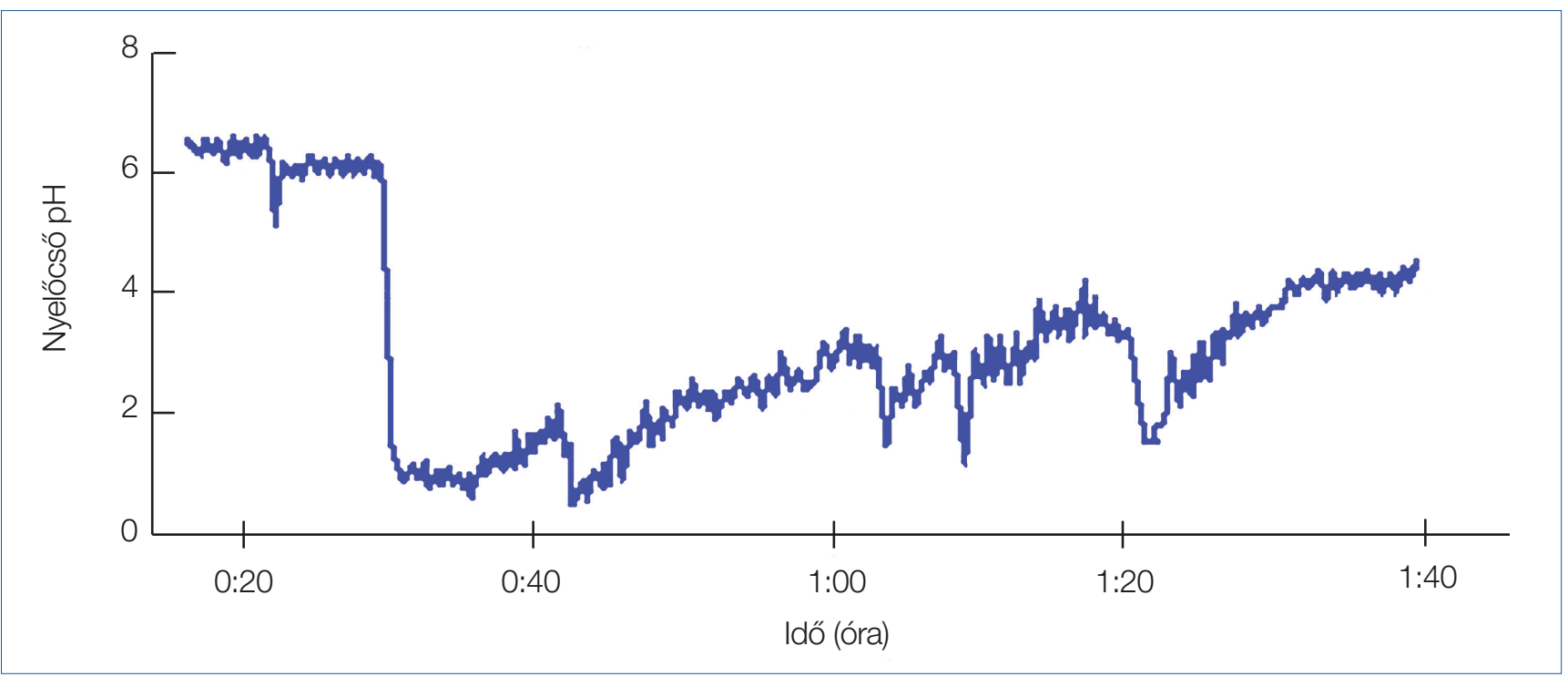


járó cirkadián ritmuszavarokat előrehaladott vagy késleltetett alvás fázisú típusokra, ,pacsirtákra” és „,baglyokra” osztjuk. A ritmusvesztéssel járó cirkadián rendellenességek példája jet lag és többműszakos munkakör. A cirkadián óra rendellenességei természetszerűleg kihatnak a szerveinkben található al-cirkadián órákra is, így az étkezéssel összefüggő órára. A táplálkozási óra zavarának két típusos, gyakori megjelenése van: az éjszakai étkezési szindróma és a több műszakban végzett munka során kialakult megváltozott étkezési mintázat. Éjszakai étkezési szindróma esetén a bizonyítékok azt igazolják, hogy a veleszületett táplálkozási ritmus késik, tehát a fő táplálkozási időszak későbbre tolódik egy szokásos napon (5).

A betegek között nagyon gyakori a késői alvásfázis-szindróma (bagolytípus) és ők késő estig nem éhesek, viszont reggel étvágytalanok. Az étkezési oszcillátorok működészavara, szoros összefüggésben van a több műszakos munkakörökhöz társuló obesitással és metabolikus eltérésekkel (6).

A cirkadián ritmus fontos szerepet játszik a metabolikus folyamatok szabályozásában. Ez magyarázhatja a több műszakos munkavégzés következményeit, a rövidebb alvás időtartam és az alvás fragmentáltsága testsúlygyarapodáshoz, elhízáshoz és anyagcsere-zavarokhoz vezethet. Az alvás deprivációja önmagában befolyásolja a kalóriabevitelt, a glükózfelhasználást és a leptinrezisztenciát (7).

\section{Az emésztés kezdete}

Az emésztés a szájban kezdődik, mint a rágás, a nyálképzés és a nyelés folyamata. Ezek a kezdeti emésztési folyamatok az ébrenléti állapothoz kapcsolódnak. Bár a rágás nyilvánvalóan csökken az alvás során, de a nyáltermelés drámaian csökken alvás közben, 0,5 ml/perc sebességről a nullához közeli értékre $(8,9)$.

A nyál pH-ja szintén csökken éjszaka. Hasonlóképpen, a nyelési arány ébrenlétkor kb. 25/óráról 5/órára csökken alvásban. A nyelés alvás közbeni csökkenése ellenére, a légutat védi a cricopharyngealis izomzat, amely nyomás barriert alakít ki a proximális nyelőcsőszakaszban az as- piráció megakadályozására. Ez az izom egyedülállóan a REM-alvás ideje alatt, a REM során általánosan kialakuló teljes izomatónia ellenére megtartja a tónusát (10).

A nyelés során a folyamatnak le kell győznie a cricopharyngealis izomzat és a felső esophagealis sphincter nyomásának ellenállását, hogy a falat bejuthasson a nyelőcsőbe. Bár az előbbi megtartja az összehúzódást, az utóbbi zárónyomása csökken a mély alvás során az ébrenléti érték kevesebb, mint 25\%-ára.

A nyelés a nyelőcső perisztaltikáját inicializálja, de ez fokozatosan csökken a mély NREM-alvásban és a REM-alvás során. A nyeléssel nem összefüggő másodlagos perisztaltika szintén csökken NREM-alvásban, de a REM-alvásban viszont fokozódik a centrális autonóm idegrendszer aktivitásának függvényében $(11,12)$.

Éjjel a nyelőcső kontrakciói csökkennek (13).

Az alsó oesophagealis sphincter (LES) tónusa szintén csökken az alvás során, de típusosan az intragastricus nyomás fölött marad. Ugyanakkor a LES-nyomás 5-30 másodperces csökkenését is észlelték az intraabdominális nyomás hirtelen növekedésével párhuzamosan az alvás során, amely gyomorrefluxhoz vezet (14).

Ezért alvás közben a nyelőcső jóval vulnerábilisabb lesz a gyomorsav hatására az alacsonyabb nyelési szám, a csökkent nyálmennyiség és megváltozott Ph, továbbá a csökkent perisztaltika miatt, amely megnöveli a gyomorsavnyálkahártya érintkezési időt.

\section{Gastrooesophagealis refluxbetegség}

A gyomor-nyelőcső refluxbetegséget mind a cirkadián, mind az alvás során kialakuló tényezők befolyásolják, és ezek alapján megkülönböztetjük az éjszakai refluxot a nappali refluxtól (15).

A cirkadián ritmus és az alvás stádiumok alatti állapot csökkenti a reflux epizódok elleni védekezést. Az alvás közben fellépő reflux események az ébrenlét eseményeivel összehasonlítva ritkábbak, de a csökkent nyelőcsőclearance miatt lényegesen hosszabb érintkezési idővel rendelkeznek (1-2. ábra). A nyálkahártya-károsodás lehe-

\section{2. ábra: Normál posztprandiális reflux}

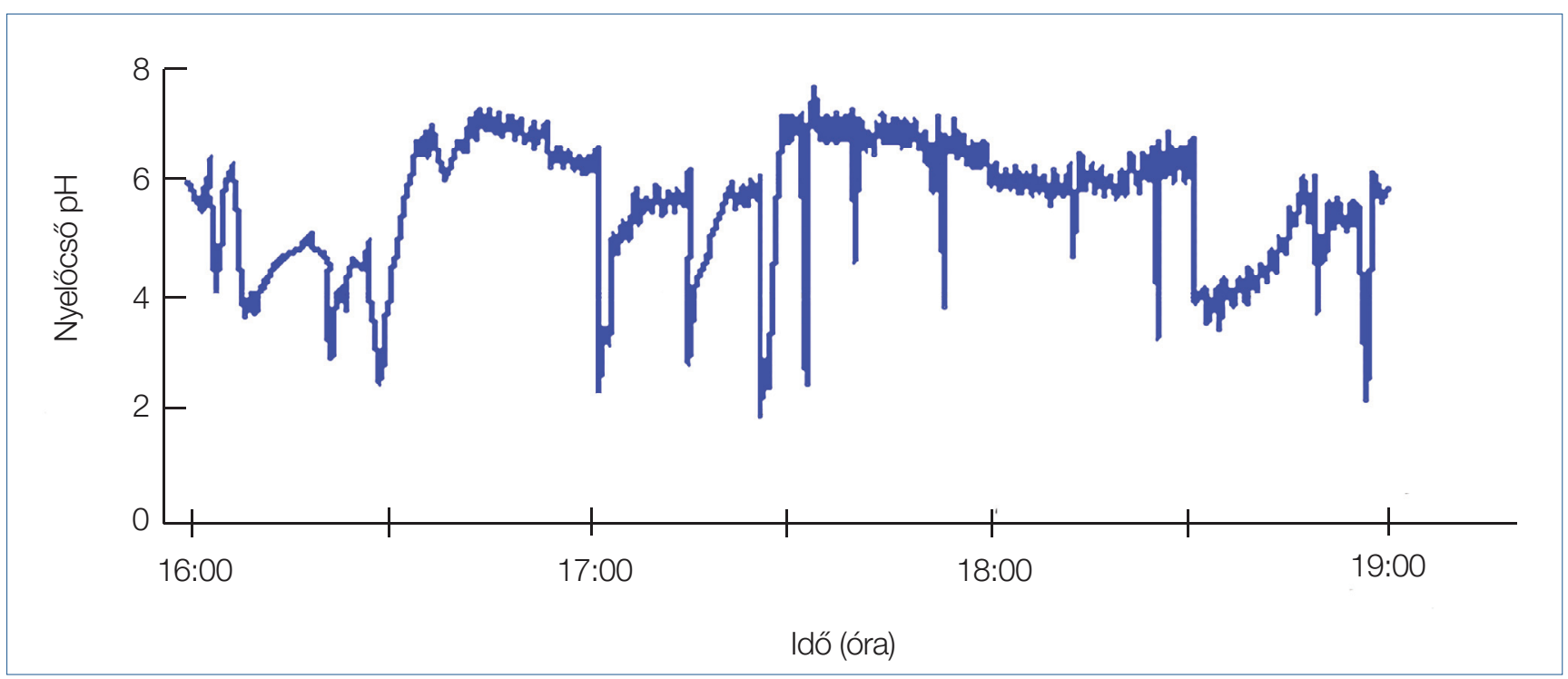


tősége jelentősen fokozódik olyan faktorok, mint a csökkent nyáltermelés (különösen a bikarbonát), a csökkent nyelési frekvencia, a csökkent LES-nyomás és a csökkent ébredési (arousal) reakciók, valamint olyan cirkadián-függő tényezők, mint a megnövekedett gyomorsav-termelés és a késleltetett gyomortartalom-ürítés következtében. $A$ nyelőcső védőmechanizmusainak elvesztése és a nagyobb savexpozíció korrelál az oesophagitis és a nyálkahártya-károsodás kockázatával (16). Megjegyzendő, hogy egy fragmentált alvást követően, másnap éjjel jóval több refluxeseményt rögzítettek a pH-monitorizálás esetén (17).

\section{A gyomor}

A gyomor fő feladatai közé tartozik az elfogyasztott ételek savanyítása és az étel-bólusok duodenumba történő áramoltatása. A savszekréció segíti az organizmusok emésztőrendszerbe jutásának megakadályozását, és néhány fehérjét denaturál a könnyebb emésztés érdekében. Az ételek szabályozott áramlása a vékonybélbe segítheti a tápanyagok felszívódásának optimalizálását.

Az alvás és a cirkadián ritmus befolyásolja a savszekréciót és a gyomor motoros aktivitását. A savszekréció mértéke éjszakáról éjszakára nagymértékben változik, mégis 22 és 02 óra között kicsúcsosodva maximalizálódik, ami cirkadián befolyásolásra utal (3. ábra) (18). A vagotómián átesett embereknél ezt a csúcsot nem látják, jelezve a közvetlen paraszimpatikus hatást. REM-alvás során a savszekréció gátlódik (19). Az ébrenléti gyomor pH-ját összehasonlítva, az értékek magasabbak voltak NREM-ben és még magasabbak a REM-alvásban (20). Érdekes módon a kutatók azt találták, hogy a nyombélfekélyben szenvedő betegek elveszítették ezeket a savszekréciós ritmusokat (19).

A nyombélfekélyek patogenezisének vizsgálata során folyamatos savtúltermelést igazoltak éjjel-nappal. A savszekréciós ritmus eltűnését a fekélyképződés egyik okaként feltételezik. A savtúltermelés kapcsolatos a krónikus Helicobacter pylori fertőzéssel. Ez az organizmus csökkenti a szomatosztatinszintet, ami viszont lehetővé teszi a fedősejtek mennyiségének növekedését és a cirkadián mintázat nélküli sav túltermelését (21).

Ezeknél a betegeknél a savszekréció cirkadián ritmicitásának elvesztése megakadályozza a duodenális nyálkahártya teljes felépülését. Ezeknek a fekélyeknek a kezelése sikeresebb, ha antibiotikumokat protonpumpa-gátlóval együtt alkalmaznak a savszekréció csökkentésére és a nyálkahártya helyreállítására $(22,23)$. Ezek a fekélyek jobban gyógyulnak melatonin adagolása mellett (24).

A melatonin javíthatja a nyálkahártya regenerálódását. $A$ melatonint a tobozmirigy mellett a gyomor és a nyombélnyálkahártya neuroendokrin sejtjei is termelik, segítve a belső óra (suprachiasmatikus mag) szervi szinkronizálását, ideértve az étkezést és a myoelektrikus ritmust.

A melatonin gátolja a gyomorsav-felszabadulást, növeli a gyomor vérátáramlását és javítja a nyálkahártya-regene-

\section{3. ábra: A savszekréció mértéke a nap folyamán}

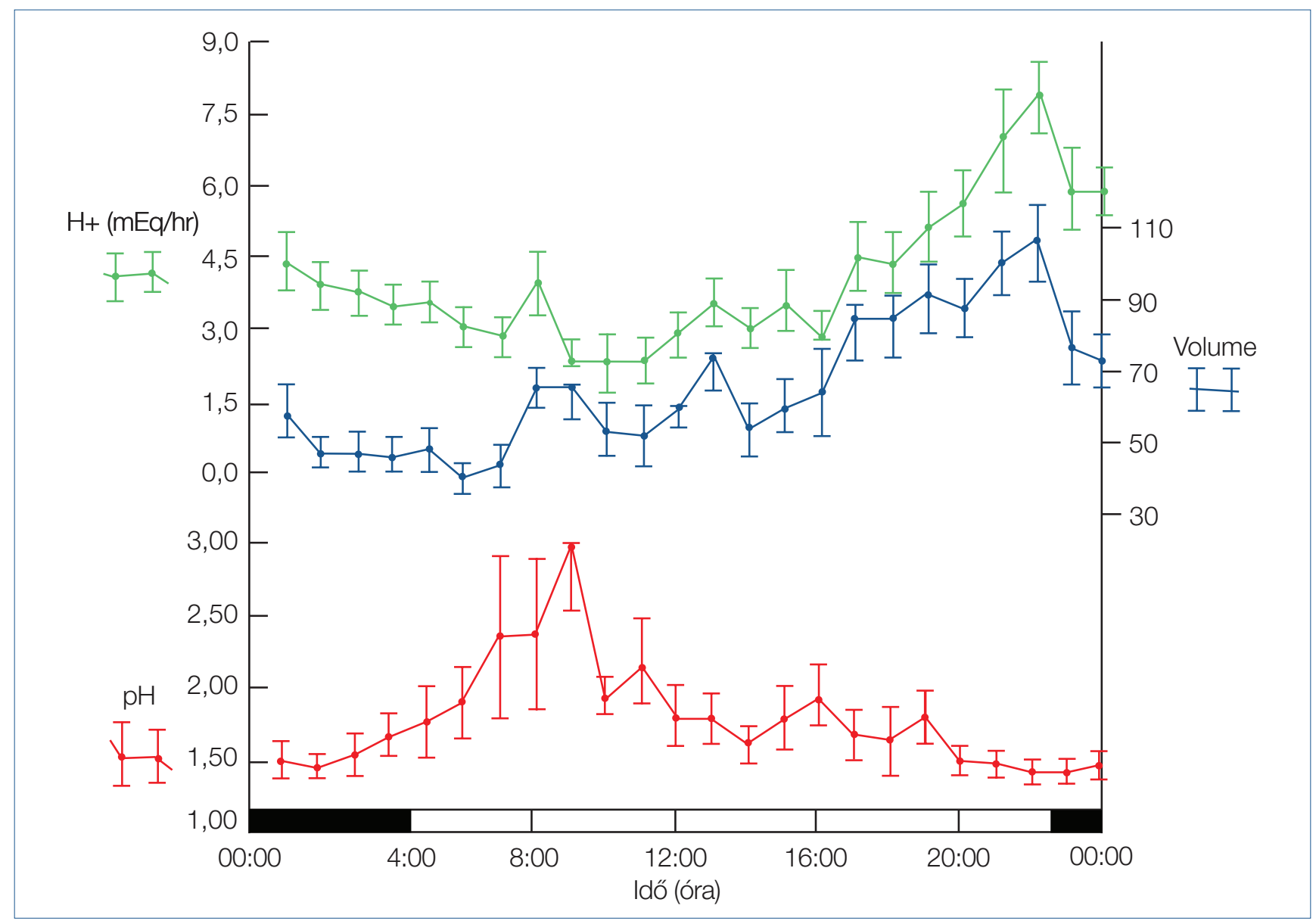


rációját. Azoknál a betegeknél, akiknél alacsonyabb mértékű a melatonin termelődése, a gyomor stresszfekélyek gyógyulása hosszabb ideig tart. Ezekben a betegekben az exogén melatonin javítja a nyálkahártya gyógyulását. Ez összefügghet a melatonin antioxidáns tulajdonságaival (25). A melatonin szintén hatással van a nyálkahártya fejlődésére és a villus magasságra, a teljes nyálkahártya vastagságára és a sejtek mitózisára (26).

A gyomor motoros vezérlése a gyomor régióiként és az étkezési bolus típusa szerint is változik. A gyomor fundusa elsősorban a folyadékáramlást, míg az antrum a szilárd tápanyagok mozgását szabályozza. Noha ezek mindegyike eltérő mechanizmusokat alkalmaz az áramlás szabályozására, végül is a gyomortartalomnak a duodenumba kell áramolnia a további emésztés céljából. A gyomor motoros funkcióját veleszületetten egy gyomor-pacemaker vezérli, amely a simaizmok elektromos generátora a gyomor proximális nagygörbületén. A gyomor motoros ciklusa két-négy hullám/perc, továbbítva a táplálékbólust a duodenum felé. A gyomor motoros ciklusának amplitúdója csökken a NREMalvás során és visszatér a REM-alvás közben $(27,28)$. Ez az aktivitás cirkadián jelleget is ölt, hiszen köztudott az esti ébrenléti órákban a gyomorürülés lassú (29).

\section{A vékonybél}

A vékonybél elsősorban a tápanyagok felszívódásáért és az étkezési bolus vastagbél felé történő továbbításáért felelős. Nem találtak változást a tápanyagok felszívódásában alvás közben (30). Az intestinális motilitás a migrációs motoros komplex (MMC) manifesztációja. Időszakos összehúzódásként indul meg a gyomorban és migrál a vastagbélbe. Számos szerző az MMC sebességének csökkenését találta a késő esti étkezést követően $(31,32)$.

Az alvásfüggő MMC időtartama hosszabb a menstruációs ciklus korai follikuláris fázisában (33). A kora esti alkohol fokozhatja a jejunum kontrakciójának amplitúdóját alvás közbe (34). A táplálék indukálta gasztrin, neurotenzin,
YY-peptid és hasnyálmirigy-polipeptidek szekrécióját az alvás nem befolyásolja (30). Más exokrin funkciókat vizsgálva megállapították, hogy az amilázkibocsátás növekszik, míg a proteázkibocsátás nem változik alvás közben (35). Ezek a tanulmányok arra utalnak, hogy az alvás során az intestinalis motilitásra gyakorolt hatásokat megváltoztathatják más non-digesztív endokrin, illetve más neurális hatások.

\section{A vastagbél}

Az emberi vastagbélnek két fő funkciója van: a víz abszorpciója és a bél anyagának átmeneti tárolása. A vastagbél motoros funkciója egy komplex, nem ciklikus esemény, amely független a kisebb méretű motoros összehúzódásoktól, amelyek a székletet caudal felé mozgatják (36). Az ürülék kaudális irányba történő továbbításának és a kontinencia fenntartásának egymással ellentétes funkciói összehangolt motoros működést igényelnek. A vastagbél motilitása csökken az alvás során. Azok a colonkontrakciók, amelyek az ürüléket kaudál felé propagálják szignifikánsan csökkennek az éj folyamán és a lassú hullámú alvás során szinte meg is szűnnek. Bár a REM-alvás megnövekedett colon intralumináris nyomással jár, a propagáló kontrakciók frekvenciája hasonló a NREM 2-es fázishoz. Hasonlóan az ébrenléthez az átmeneti ébredések (arousal) szignifikánsan emelik a propagáló kontrakciókat a colon minden szegmensében $(37,38,39)$.

A széklet tárolása, kontinenciája érdekében a rectum izmaiban és az analis sphincterben komplex ciklikus motoros aktivitás figyelhető meg. Ez az aktivitás leállítja colonhullámok aktivitását és retrográd propagációjú kontrakciós hullámokat produkál (40). Alvás közben a belső anális sphincter megtartja az aktivitását, függetlenül a külső sphincter aktivitásától, ami azt sugallja, hogy a két sphincter eltérő szabályozás kontrollja alatt áll $(41,42)$. Ezért az anális csatorna nyomása a végbélnyomás felett marad, így biztosítván az alvás során is a kontinenciát (43).

\section{Irodalom}

1. Lowrey PL, Takahashi JS. Genetics of circadian rhythms in mammalian model organisms. Adv Genet 2011; 74: 175-230.

2. Moszczynskia A, Murray BJ. Neurobiological aspects of sleep physio logy. Neurol Clin 2012; 30: 963-985.

3. Patton DF, Mistlberger RE. Circadian adaptations to meal timing: neuroendocrine mechanisms. Front Neurosci 2013; 7: 185

4. Lamont EW, Bruton J, Blum ID, Abizaid A. Ghrelin receptor-knockout mice display alterations in circadian rhythms of activity and feeding under constant lighting conditions. Eur J Neurosci 2014; 39: 207-217.

5. Milano W, De Rosa M, Milano L, Capasso A. Night eating syndrome: an overview. J Pharm Pharmacol 2012; 64: 2-10.

6. Sherman H, Genzer Y, Cohen R, Chapnik N, Madar Z, Froy O. Timed high-fat diet resets circadian metabolism and prevents obesity. FASEB $\mathrm{J}$ 2012; 26: 3493-3502.

7.Spiegel K, Tasali E, Leproult R, et al. of poor and short sleep on glucose metabolism and obesity risk. Nat Rev Endocrinol 2009; 5: 253-261.

8. Schneyer LH, Pigman W, Hanahan L, Gilmore RW. Rate of flow of human parotid, sublingual, and submaxillary secretions during sleep. J Dent Res 1956; 35: 109-114.

9. Lear CS, Flanagan JB Jr, Moorrees CF. The frequency of deglutition in man. Arch Oral Biol 1965; 10: 83-100.

10. Kahrilas PJ, Dodds WJ, Dent J, Haeberle B, Hogan WJ, Arndorfer RC. Effect of sleep, spontaneous gastroesophageal reflux, and a meal on upper esophageal sphincter pressure in normal human volunteers. Gastroenterology 1987; 92: 466-471.

11. Castiglione F, Emde C, Armstrong D, et al. Nocturnal oesophageal motor activity is dependent on sleep stage. Gut 1993; 34: 1653-1659.

12. Orr WC, Elsenbruch S, Harnish MJ, Johnson LF. Proximal migration of esophageal acid perfusions during waking and sleep. Am J Gastroenterol 2000; 95: 37-42

13. Stein HJ, Singh S, Demeester TR. "Efficacy" of esophageal peristalsis: a manometric parameter to quantify esophageal body dysfunction. Dis Esophagus 2004; 17: 297-303.

14. Dent J, Dodds WJ, Friedman RH, et al. Mechanism of gastroesophageal reflux in recumbent asymptomatic human subjects. J Clin Invest 1980; 65: 256-267.

15. Johnson LF, Demeester TR. Twenty-four-hour $\mathrm{pH}$ monitoring of the distal esophagus. A quantitative measure of gastroesophageal reflux. Am J Gastroenterol 1974; 62: 325-332.

16. Orr WC, Johnson LF, Robinson MG. Effect of sleep on swallowing, esophageal peristalsis, and acid clearance. Gastroenterology 1984; 86: 814-819.

17. Dickman R, Green C, Fass SS, et al. Relationships between sleep quality and $\mathrm{pH}$ monitoring findings in persons with gastroesophageal reflux disease. J Clin Sleep Med 2007; 3: 505-513.

18. Moore JG. Circadian dynamics of gastric acid secretion and pharmacodynamics of H2 receptor blockade. Ann N Y Acad Sci 1991; 618: 150-158.

19. Stacher G, Presslich B, Starker H. Gastric acid secretion and sleep stages during natural night sleep. Gastroenterology 1975; 68: 1449-1455. 20. Watanabe M, Nakazawa S, Yoshino J, et al. [A study of the relationship between nocturnal intragastric $\mathrm{pH}$ and sleep stages of peptic ulcer]. Nippon Shokakibyo Gakkai Zasshi 1995; 92: 1241-1249. Japanese.

21. Schubert ML, Peura DA. Control of gastric acid secretion in health and disease. Gastroenterology 2008; 134: 1842-1860.

A további irodalom megtalálható a szerkesztőségben, valamint

a www.gastronews.hu weboldalon. 